\title{
Maximum temperatures over Slovenia and their relationship with atmospheric circulation patterns
}

DRAGAN D. MILOŠEVIĆ ${ }^{1}$, STEVAN M. SAVIĆ ${ }^{1}$, UGLJEŠA STANKOV ${ }^{2}$, IGOR ŽIBERNA ${ }^{3}$, MILANA M. PANTELIĆ ${ }^{1}$, DRAGAN DOLINAJ ${ }^{1}$, IGOR LEŠČEŠEN ${ }^{4}$

${ }^{1}$ University of Novi Sad, Faculty of Sciences, Climatology and Hydrology Research Centre, Serbia; e-mail: dragan.milosevic@dgt.uns.ac.rs

${ }^{2}$ University of Novi Sad, Faculty of Sciences, Center for Spatial Information of Vojvodina Province, Serbia

${ }^{3}$ University of Maribor, Faculty of Arts, Department of Geography, Slovenia

${ }^{4}$ University of Novi Sad, Faculty of Sciences, Department of Geography, Tourism and Hotel Management, Serbia

ABSTRACT This paper examines temporal and spatial patterns of annual and seasonal maximum temperatures $\left(T_{\max }\right)$ in Slovenia and their relationship with atmospheric circulation patterns. A significant increase in maximum temperature $\left(T_{\max }\right.$; from $0.3^{\circ} \mathrm{C}$ to $0.5^{\circ} \mathrm{C} \cdot$ decade $\left.^{-1}\right)$ was observed throughout the country at the annual scale in the period 1963-2014. Significant positive trends are observed on all stations in summer (from $0.4^{\circ} \mathrm{C}$ to $0.7^{\circ} \mathrm{C} \cdot$ decade $^{-1}$ ) and spring (from $0.4^{\circ} \mathrm{C}$ to $0.6^{\circ} \mathrm{C} \cdot$ decade $^{-1}$ ). The results indicate significant correlations between the mean annual maximum temperature ( $T_{\max }$ ) and the East Atlantic Oscillation (EA) (from 0.5 to 0.7), the Arctic Oscillation (AO) (from 0.4 to 0.7) and the Scandinavian Oscillation (SCAND) (from -0.3 to -0.4) throughout the country. A significant EA influence is observed in all seasons, while the AO influence is noticed in winter and spring, SCAND in spring and summer, the North Atlantic Oscillation (NAO) and the Mediterranean Oscillation (MO) in winter, the East Atlantic/Western Russia Oscillation (EA/WR) in summer and the El Nino Southern Oscillation (ENSO) in autumn.

KEY WORDS maximum temperature - trends - atmospheric circulation - Slovenia

MILOŠEVIĆ, D.D., SAVIĆ, S.M., STANKOV, U., ŽIBERNA, I., PANTELIĆ, M.M., DOLINAJ, D., LEŠČEŠEN, I. (2017): Maximum temperatures over Slovenia and their relationship with atmospheric circulation patterns. Geografie, 122, 1, 1-20.

Received June 2015, accepted May 2016.

CC Česká geografická společnost, z. s., 2017 


\section{Introduction}

Changes in maximum temperature $\left(T_{\max }\right)$ frequency, intensity and duration can influence different human activities (e.g. agriculture, tourism, etc.) and ecosystems. Due to this, investigation of $T_{\max }$ variability and trends has been performed in numerous studies. During the twentieth century, maximum and minimum temperatures in Europe have warmed more in winter $\left(1.0^{\circ} \mathrm{C} / 100\right.$ years $)$ than summer $\left(0.8^{\circ} \mathrm{C} / 100\right.$ years; Moberg et al. 2006). Temperatures have risen faster than the global average in the Mediterranean region in the last decades (Lionello et al. 2014) with strong enhancement in the occurrence of extremely warm events (Simolo et al. 2014).

Significant progresses have been made on the climate projections for the Mediterranean region (Branković et al. 2012, Vautard et al. 2013, Lionello et al. 2014). Study of Giorgi (2006) showed that the most responsive region to climatic change is Mediterranean followed by the North Eastern European regions. Best accordance among future projections can be found in seasonal temperatures with lower rates of warming in winter and spring and higher rates in summer and autumn. Furthermore, high-temperature conditions are generally expected to increase (Jacobeit et al. 2014). Future climate conditions for the Mediterranean region are characterized by an increase in temperature in all seasons and for all parts of the Mediterranean with a trend toward more extreme weather (Dubrovský et al. 2014).

Slovenia is situated in Central Europe on the contact of four distinct geographical regions: the Mediterranean Sea, the Alps, the Dinaric Alps and the Pannonian Basin (Orožen Adamič 2004). Slovenia extends between $45^{\circ} 25^{\prime}$ and $46^{\circ} 30^{\prime} \mathrm{N}$ and $13^{\circ} 23^{\prime}$ and $16^{\circ} 36^{\prime} \mathrm{E}$ (Ogrin, Plut 2009) and covers an area of $20,273 \mathrm{~km}^{2}$ (Orožen Adamič 2004) with population of 2.06 million. Alpine macroregion covers northern Slovenia, while Mediterranean macroregion is located in the extreme west of Slovenia. Toward the east, the Mediterranean macroregion is replaced by the Dinaric macroregion that stretches in a northwest-southeast direction and covers most of the southern part of Slovenia. Pannonian macroregion is a densely populated and intensively cultivated area at the east end of Slovenia (Perko 1998).

Submediterranean, temperate continental and alpine climatic influences intertwine on the territory of Slovenia. However, most of Slovenia has a temperate continental climate. Alpine climate characterizes higher and lower mountain areas to the north and west of the country, while submediterranean climate is present in the south and southwest of the country at the Adriatic coast (coastal submediterranean climate) and its hinterland (inland submediterranean climate). Continental climate intensifies with the distance increase from the Adriatic Sea and Alps-Dinaric mountain barrier towards the eastern and northeastern Slovenia 
(Ogrin 2004). According to the Köppen-Geiger classification (Kottek et al. 2006), the majority of the country is situated in the $\mathrm{Cfb}$ climate zone with littoral region partly in Cfa and the Alps in the Dfc climate zone.

Analysis of temperature changes in Slovenia has been performed in numerous studies (Milošević, Savić, Žiberna 2013; Milošević, Žiberna, Savić 2013; De Luis et al. 2014; Vertačnik et al. 2015). The analysis of Milošević, Savić, Žiberna (2013) showed statistically significant positive trend of mean (from $1.4^{\circ} \mathrm{C} / 51$ years to $2.4^{\circ} \mathrm{C} / 51$ years), maximum (from $1.3^{\circ} \mathrm{C} / 51$ years to $2.4^{\circ} \mathrm{C} / 51$ years) and minimum (from $1.7^{\circ} \mathrm{C} / 51$ years to $2.9^{\circ} \mathrm{C} / 51$ years) annual temperatures in the period 1961-2011. Temperature rise has been particularly pronounced in summer, spring and winter. Growing season in Slovenia has extended (up to 25 days / 51 years) due to the warming in mean, maximum and minimum temperature (Milošević, Žiberna, Savić 2013). De Luis et al. (2014) noticed intense warming of mean air temperatures in Slovenia in summer and spring and weak warming in autumn. Linear trend of around $0.3-0.4^{\circ} \mathrm{C} \cdot$ decade $^{-1}$ on an annual level for mean, maximum and minimum temperature series has been noticed in Slovenia in the last five decades (Vertačnik et al. 2015).

Atmospheric circulation patterns refer to a large and persistent pattern of pressure anomalies that influence the flow of air masses that affect the climatic characteristics of broad geographical regions (Hurrell 1995). The correlations between atmospheric circulation indices and temperature are very important to analyze as the local changes in meteorological variables in mid-latitudes are mainly controlled by the atmospheric circulation (Hurell 1995; Hurell, Van Loon 1997). Air temperature and its extremes have been correlated with atmospheric circulation indices in numerous studies (Kenyon, Hegerl 2008; Rodriguez-Puebla et al. 2010; Dobrovolný et al. 2010; Toreti et al. 2010; Efthymiadis et al. 2011; El Kenawy et al. 2012; Donat et al. 2014). The relationships between circulation pattern indices and temperature in Slovenia have not been well identified. Sušelj, Bergant (2006) analyzed the influence of NAOi and MOi on mean, maximum and minimum temperature on four stations located in different climatic regions of Slovenia. According to this study, significant positive correlations have been established between NAOi, MOi and temperatures (especially maximum) during colder part of the year with higher correlations of temperature with MOi.

The main aims of this paper are to analyze temporal and spatial variability of annual and seasonal $T_{\max }$ in Slovenia and to correlate it with indices of the atmospheric circulation patterns influencing the Mediterranean region: Arctic Oscillation index (AOi), East Atlantic Oscillation index (EAi), East Atlantic/Western Russia Oscillation index (EA/WRi), El Nino Southern Oscillation (ENSOi), Mediterranean Oscillation index (MOi), North Atlantic Oscillation index (NAOi), Scandinavian Oscillation (SCANDi) and Western Mediterannean Oscillation index (WeMOi). Results of this analysis will quantify possible relationships between 
atmospheric patterns and observed $T_{\max }$ in Slovenia and fill the gap in the understanding of these correlations in this transitional area.

\section{Data and methods}

Annual and seasonal $T_{\max }$ recorded at 19 stations in Slovenia in the period 1963-2014 were analyzed (Table 1). Selected stations are located on the territory of different climatic regions of Slovenia: Submediterranean climatic region (2 stations), Temperate continental climatic region (13 stations) and Mountain climatic region (4 stations). Selection of adequate number of stations in each climatic region was based on its size and average altitude as well as data availability and homogeneity.

Monthly temperature was obtained from the Environmental Agency of the Republic of Slovenia (EARS). Winter (DJF), spring (MAM), summer (JJA) and autumn (SON) temperature was calculated for each station using the standard season definition. All seasons correspond to the calendar year except for the winter season that corresponds to January-February of the calendar year and to December of the previous year. $T_{\max }$ measurements were taken at 21 LMT (Local Mean Time - UTC+1).

Tab. 1 - List of stations with their basic geographical informations: latitude (Lat.), longitude (Long.) and altitude (Alt.)

\begin{tabular}{|c|c|c|c|c|c|}
\hline Full name & Abbreviation & Lat. & Long. & Alt. (m) & Climate type \\
\hline Kredarica & KR & $46^{\circ} 23^{\prime}$ & $13^{\circ} 51^{\prime}$ & 2,514 & Mountain \\
\hline Postojna & PO & $45^{\circ} 46^{\prime}$ & $14^{\circ} 12^{\prime}$ & 533 & Temperate continental \\
\hline Ljubljana-Bežigrad & LJB & $46^{\circ} 04^{\prime}$ & $14^{\circ} 31^{\prime}$ & 299 & Temperate continental \\
\hline Novo Mesto & NM & $45^{\circ} 48^{\prime}$ & $15^{\circ} 11^{\prime}$ & 220 & Temperate continental \\
\hline Celje & $\mathrm{CLJ}$ & $46^{\circ} 15^{\prime}$ & $15^{\circ} 15^{\prime}$ & 240 & Temperate continental \\
\hline Maribor-Tabor & $M B$ & $46^{\circ} 32^{\prime}$ & $15^{\circ} 39^{\prime}$ & 275 & Temperate continental \\
\hline Šmartno pri Slovenj Gradcu & SS & $46^{\circ} 29^{\prime}$ & $15^{\circ} 07^{\prime}$ & 445 & Mountain \\
\hline Murska Sobota & MS & $46^{\circ} 39^{\prime}$ & $16^{\circ} 11^{\prime}$ & 188 & Temperate continental \\
\hline Bilje & BLJ & $45^{\circ} 54^{\prime}$ & $13^{\circ} 38^{\prime}$ & 55 & Submediterannean \\
\hline Lendava & LD & $46^{\circ} 34^{\prime}$ & $16^{\circ} 28^{\prime}$ & 195 & Temperate continental \\
\hline Veliki Dolenci & VD & $46^{\circ} 50^{\prime}$ & $16^{\circ} 17^{\prime}$ & 308 & Temperate continental \\
\hline Godnje & GD & $45^{\circ} 45^{\prime}$ & $13^{\circ} 51^{\prime}$ & 320 & Submediterannean \\
\hline Rateče-Planica & RT & $46^{\circ} 30^{\prime}$ & $13^{\circ} 43^{\prime}$ & 864 & Mountain \\
\hline Brnik-Letališče & $B R$ & $46^{\circ} 13^{\prime}$ & $14^{\circ} 29^{\prime}$ & 364 & Temperate continental \\
\hline Kočevje & KO & $45^{\circ} 39^{\prime}$ & $14^{\circ} 51^{\prime}$ & 467 & Temperate continental \\
\hline Dobliče (Črnomelj) & DO & $45^{\circ} 34^{\prime}$ & $15^{\circ} 09^{\prime}$ & 157 & Temperate continental \\
\hline Bizeljsko & $B Z$ & $46^{\circ} 01^{\prime}$ & $15^{\circ} 42^{\prime}$ & 179 & Temperate continental \\
\hline Slovenske Konjice & SK & $46^{\circ} 20^{\prime}$ & $15^{\circ} 26^{\prime}$ & 332 & Temperate continental \\
\hline Nova Vas (Bloke) & NV & $45^{\circ} 46^{\prime}$ & $14^{\circ} 31^{\prime}$ & 722 & Mountain \\
\hline
\end{tabular}


Standard Normal Homogeneity Test (SNHT) was applied for the detection of abrupt homogeneity breaks (Alexandersson 1986) in mean monthly $T_{\max }$ values. The test is based upon the assumption that the difference between $T_{\max }$ series at a candidate station (the one being tested) and the reference series is fairly constant in time. Reference series were chosen from 2 to 5 stations, based on distance $(<50 \mathrm{~km})$, similar altitude $(<200 \mathrm{~m})$ and squared correlation coefficient $>0.8$ with the test station. The critical level of this test was 95\% (Khaliq, Ouarda, 2007). An-Clim software package was used for the inhomogeneity detection of time series and its corrections (Štěpánek 2007).

Trends of annual and seasonal $T_{\max }$ series were detected using linear regression based on the least square method. Mann-Kendall non-parametric statistical test (Sneyers 1990) was used in order to determine the statistical significance of trends. MAKESENS calculation macro developed by the Finnish Meteorological Institute (Salmi et al. 2002) was used for the calculations.

Relationships between the $T_{\max }$ and selected atmospheric circulation pattern indices were examined using Spearman's rank correlation. Eight atmospheric circulation patterns indices were used: AOi, EAi, EA/WRi, ENSOi, MOi, NAOi, SCANDi and WeMOi. Monthly values of AOi, EAi, EA/WRi, ENSOi, SCANDi and NAOi were obtained from the National Oceanic and Atmospheric Association (NOAA) Climate Prediction Center (CPC) Website (http://www.cpc.ncep.noaa.gov/ products/precip/CWlink/pna/nao.shtml) for the period 1963-2014. Daily values of MOi were obtained from Climatic Research Unit website (http://www.cru.uea. ac.uk/cru/data/moi/) for the period 1963-2013. Monthly WeMOi data was obtained from the University of Barcelona webpage (http://www.ub.edu/gc/English/wemo. $\mathrm{htm}$ ) for the period 1963-2013. Annual and seasonal AOi, EAi, EA/WRi, ENSOi, MOi, NAOi, SCANDi and WeMOi were calculated using monthly series, while annual and seasonal MOi was calculated using daily series.

The spatial distribution of the results is shown by spatial interpolation (Inverse Distance Weighting - IDW) of observed temperature, trends and correlations on 19 stations using the geostatistical software package ARCGIS 10.1 with Geostatistical Analyst Extension.

\section{Results}

\subsection{Results of homogenisation}

Climate time series are considered homogenous only if their variability is related to weather and climate variability (Savić et al. 2012). In reality, long time series used for climate change analyses are influenced by inhomogenieties. They are caused by the relocation of the meteorological station, the replacement of instruments 
or/and observers, changes in observation rules, changes in the environment of the meteorological station (planting or/and uprooting of trees and grass, the construction or redevelopment of the infrastructural objects, etc.), human errors in data processing, etc. (Jones et al. 1985; Karl, Williams 1987; Gullett et al. 1990; Heino 1994; Moberg, Alexandersson 1997; Peterson et al. 1998; Tuomenvirta 2001; Aguilar et al. 2003). Results of climate analyses are inaccurate if detected inhomogenieties are not treated adequately (Savić et al. 2012).

Break points were detected during the homogeneity testing of mean monthly $T_{\max }$ and they were compared to the metadata records in order to diagnose their causes (Savić et al. 2014). This information was crucial for applying the calculated corrections of the investigated series (Savić, Petrović, Milovanović 2010). In most cases, detected break points were related to the relocation of a station ( 13 breaks) or due to the change of the thermometer ( 2 breaks). Having performed a series of individual or multiple homogeneity adjustments (Moberg, Alexandersson 1997),
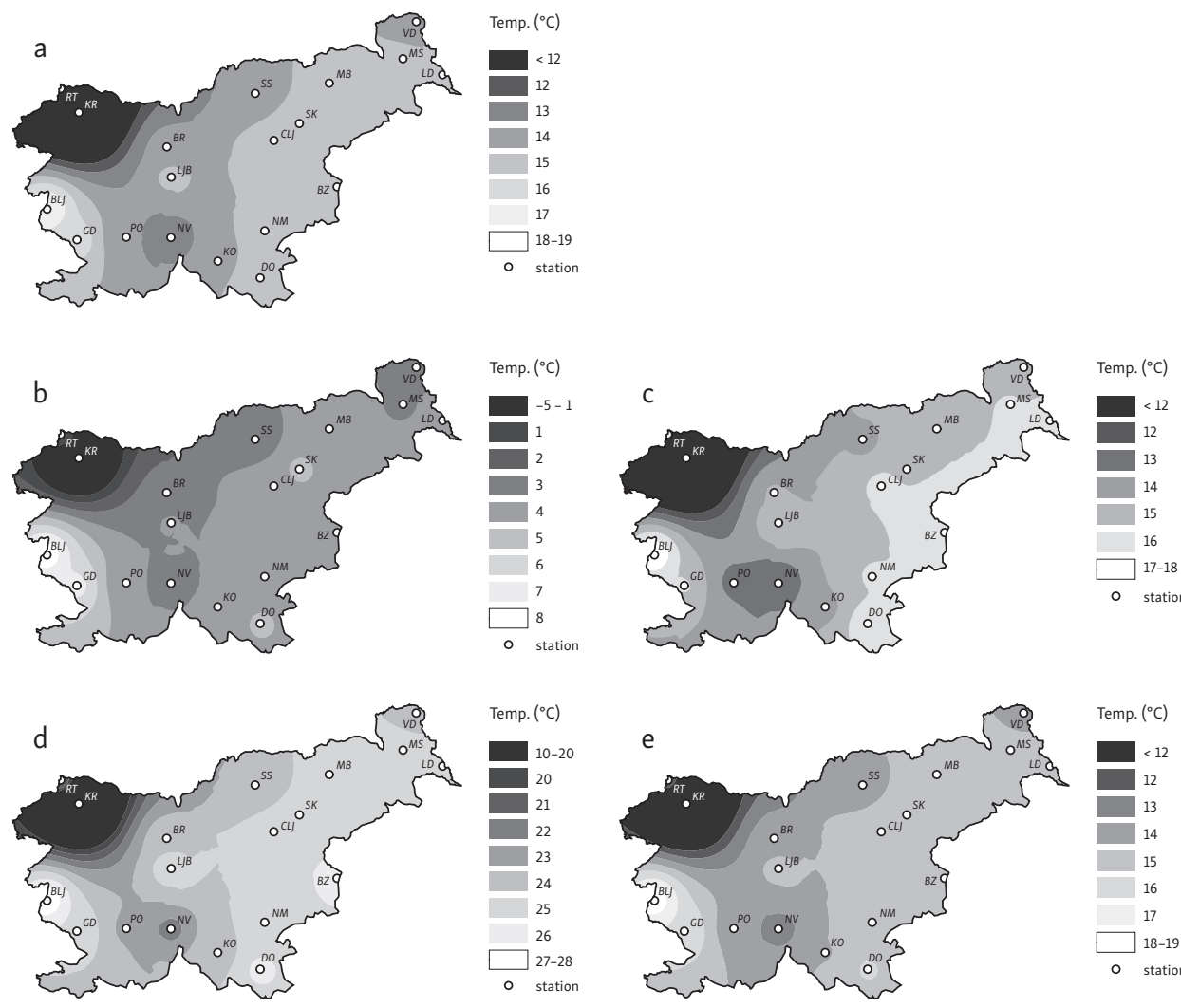

Fig. 1 - Spatial distribution of mean $T_{\max }$ in Slovenia during the 1963-2014 period; a - annual level; b - winter; c - spring; d - summer; e - autumn. 
the mean monthly $T_{\max }$ series were homogenised. The adjustment values of the monthly time series ranged from $-0.57^{\circ} \mathrm{C}$ to $0.55^{\circ} \mathrm{C}$. Homogenisation of temperature in Slovenia was also done in the study of Vertačnik et al. (2015). They had used semi-automatic homogenization approach based on metadata and obtained more reliable homogenization results compared to a fully automatic approach without metadata.

\subsection{Mean annual and seasonal $T_{\max }$ values and trends}

Mean annual $T_{\max }$ varied between $1.5^{\circ} \mathrm{C}$ in north-western Alpine part of Slovenia to $18.2^{\circ} \mathrm{C}$ in south-western Mediterranean part of Slovenia (Fig. 1a). Similar spatial distribution was noticed for mean seasonal $T_{\max }$ with values ranging from $-4.6^{\circ} \mathrm{C}$ to $8.6^{\circ} \mathrm{C}$ in winter (Fig. $1 \mathrm{~b}$ ), from $-0.7^{\circ} \mathrm{C}$ to $17.8^{\circ} \mathrm{C}$ in spring (Fig. $1 \mathrm{C}$ ), from $8.4^{\circ} \mathrm{C}$ to $27.7^{\circ} \mathrm{C}$ in summer (Fig. 1d) and from $3.0^{\circ} \mathrm{C}$ to $18.7^{\circ} \mathrm{C}$ in autumn (Fig. le). Spring was warmer than autumn on majority of the stations in the country except for the south-western Mediterranean Slovenia. The lowest seasonal $T_{\max }$ variations were noticed in the area near the Adriatic Sea with Submediterranean climatic influences.

Mean annual $T_{\max }$ in Slovenia increased from $0.3^{\circ} \mathrm{C}$ to $0.5^{\circ} \mathrm{C} \cdot$ decade $^{-1}$ during the period 1963-2014. This increase was observed throughout the country but at a lower rate in north-western Slovenia (Fig. 2a). On seasonal level, the warming was more intense in summer (from $0.4^{\circ} \mathrm{C}$ to $0.7^{\circ} \mathrm{C} \cdot$ decade $^{-1}$; Fig. $2 \mathrm{~d}$ ) and spring (from $0.4^{\circ} \mathrm{C}$ to $0.6^{\circ} \mathrm{C} \cdot$ decade $^{-1}$; Fig. $2 \mathrm{c}$ ) with a higher rate in central and eastern Slovenia. The warming was less intense in winter (from $0.2^{\circ} \mathrm{C}$ to $0.6^{\circ} \mathrm{C} \cdot$ decade $^{-1}$; Fig. $2 \mathrm{~b}$ ) and autumn (from $0.1^{\circ} \mathrm{C}$ to $0.3^{\circ} \mathrm{C} \cdot$ decade $^{-1}$; Fig. 2e) with nonsignificant trends observed in north-western and south-eastern Slovenia.

Tab. 2 - Number of stations with statistically significant correlations between $T_{\max }$ and atmospheric circulation patterns (+ statistically significant positive; - statistically significant negative; NS - statistically nonsignificant). Total number of stations is 19 .

\begin{tabular}{|c|c|c|c|c|c|c|c|c|c|c|c|c|c|c|c|}
\hline \multirow{2}{*}{$\begin{array}{l}\text { Atm. circulation } \\
\text { indices }\end{array}$} & \multicolumn{3}{|c|}{ Winter } & \multicolumn{3}{|c|}{ Spring } & \multicolumn{3}{|c|}{ Summer } & \multicolumn{3}{|c|}{ Autumn } & \multicolumn{3}{|c|}{ Annual } \\
\hline & NS & + & - & NS & + & - & NS & + & - & NS & + & - & NS & + & - \\
\hline $\mathrm{AOi}$ & 0 & 19 & 0 & 0 & 19 & 0 & 19 & 0 & 0 & 13 & 6 & 0 & 0 & 19 & 0 \\
\hline EAi & 0 & 19 & 0 & 0 & 19 & 0 & 0 & 19 & 0 & 0 & 19 & 0 & 0 & 19 & 0 \\
\hline EA/WRi & 18 & 1 & 0 & 19 & 0 & 0 & 4 & 0 & 15 & 16 & 0 & 3 & 13 & 0 & 6 \\
\hline ENSOi & 19 & 0 & 0 & 19 & 0 & 0 & 19 & 0 & 0 & 7 & 12 & 0 & 19 & 0 & 0 \\
\hline $\mathrm{MOi}$ & 1 & 18 & 0 & 19 & 0 & 0 & 18 & 1 & 0 & 19 & 0 & 0 & 13 & 6 & 0 \\
\hline NAOi & 0 & 19 & 0 & 17 & 2 & 0 & 15 & 0 & 4 & 19 & 0 & 0 & 18 & 1 & 0 \\
\hline SCANDi & 13 & 0 & 6 & 0 & 0 & 19 & 2 & 0 & 17 & 19 & 0 & 0 & 2 & 0 & 17 \\
\hline WeMOi & 18 & 0 & 1 & 18 & 0 & 1 & 19 & 0 & 0 & 18 & 0 & 1 & 12 & 0 & 7 \\
\hline
\end{tabular}



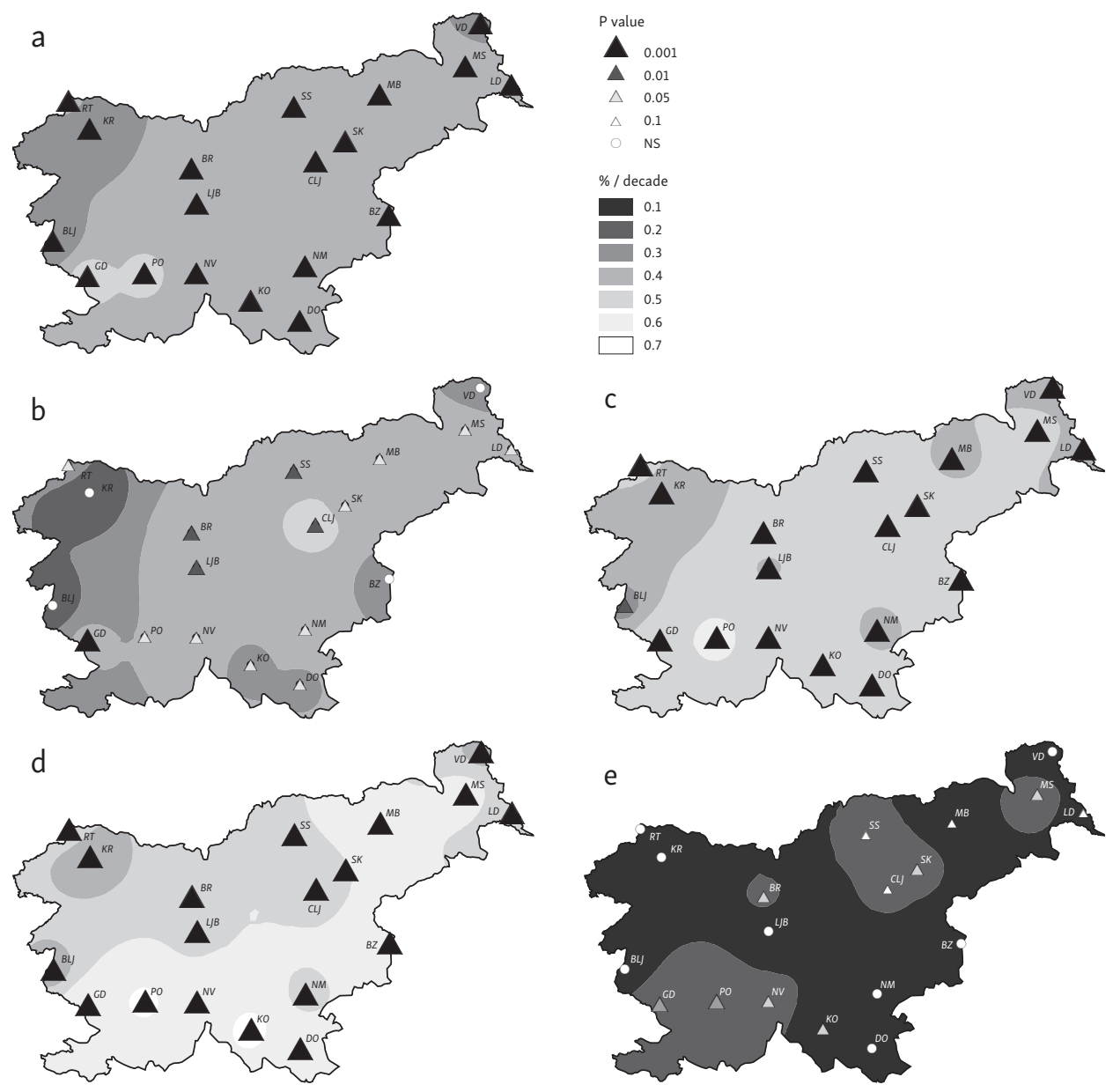

Fig. 2 - Spatial distribution of $T_{\max }$ long-term trends $\left({ }^{\circ} \mathrm{C} \cdot\right.$ decade $\left.^{-1}\right)$ in Slovenia during the 1963-2014 period: $a$ - annual, $b$ - winter, c - spring, $d$ - summer, e - autumn. Statistical significance at: $p<0.1$, $p<0.05, p<0.01$ and $p<0.001$. NS - nonsignificant.

\subsection{The correlations between atmospheric circulation patterns and $T_{\max }$}

During winter, there are statistically significant positive correlations between $T_{\max }$ and AOi (from 0.366 to 0.562 ), NAOi (from 0.387 to 0.540), MOi (from 0.318 to 0.538 ) and EAi (from 0.328 to 0.452 ) throughout Slovenia. The strongest influence of the AO pattern was noticed in north-western Slovenia (Fig. 3a), while NAO and EA pattern influence were strongest in central Slovenia (Fig. $3 \mathrm{~b}$ and $3 \mathrm{~d}$, respectively) and MO in northern Slovenia (Fig. 3c). Significant negative correlations 

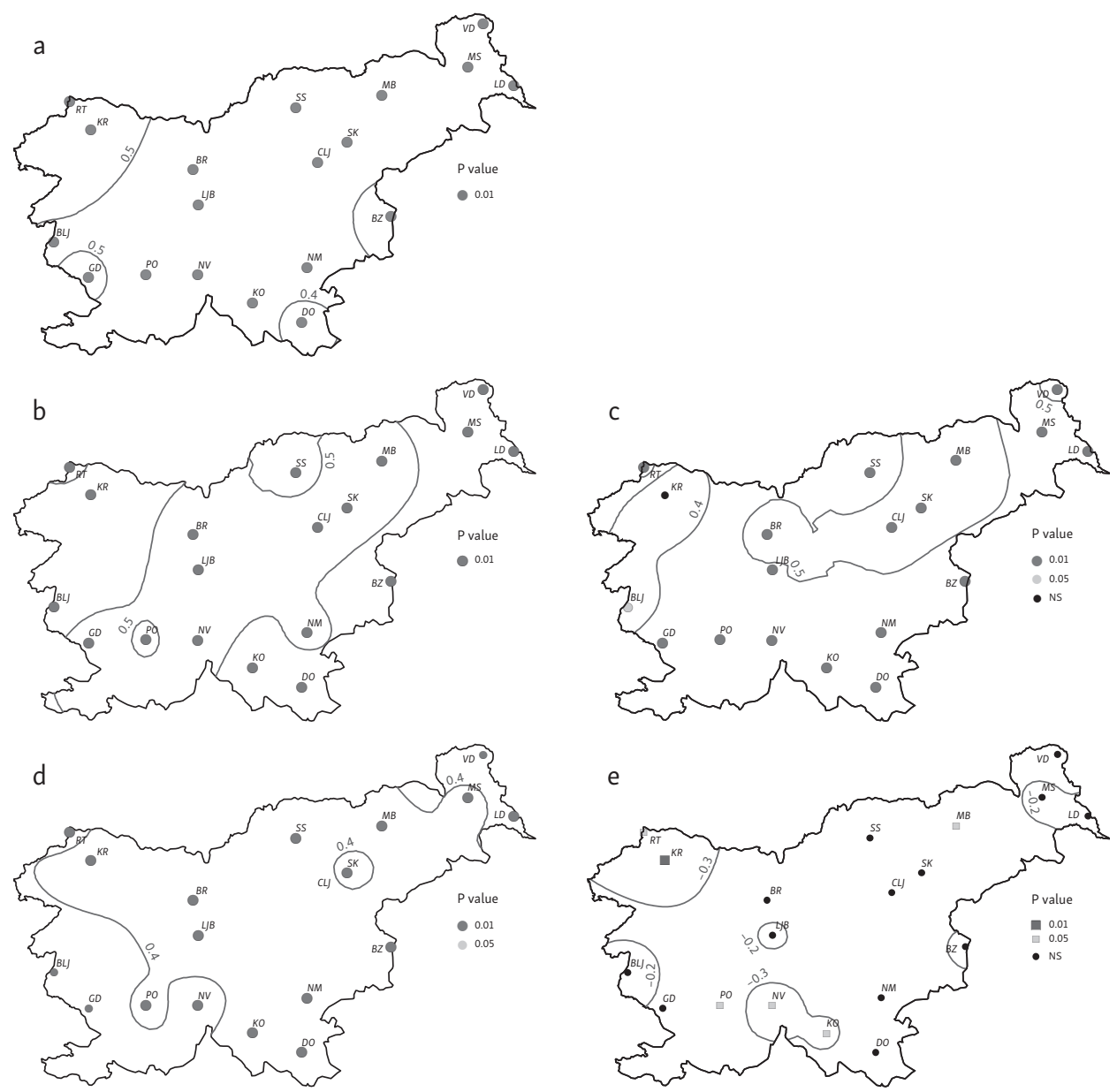

Fig. 3 - Spatial distribution of the Spearman's rank correlation coefficient between winter $T_{\max }$ and the atmospheric circulation pattern indices ( $a-A O i, b-N A O i, c-M o i, d-E A i, e-S C A N D i)$ in Slovenia during the 1963-2014 period. Significant at: $p<0.01$ and $p<0.05$. NS - nonsignificant. Circle - positive correlation and square - negative correlation.

were noticed between $T_{\max }$ and SCANDi (from -0.278 to -0.399 ) in the western part of the country (Figure $3 \mathrm{~d}$ ). Other atmospheric circulation patterns (EA/WR, ENSO and WeMO) did not show significant correlation with $\mathrm{T}_{\max }$ (Table 2).

Significant positive correlations between $T_{\max }$ and AOi (from 0.369 to 0.605 ) and EAi (from 0.278 to 0.537 ) were evident in spring throughout the country. The influence of the AO pattern was more pronounced in western Slovenia (Fig. 4a) and the EA pattern in north-western and southern Slovenia (Fig. 4b). The SCAND pattern influence had strengthened in spring and was noticed in whole of the 

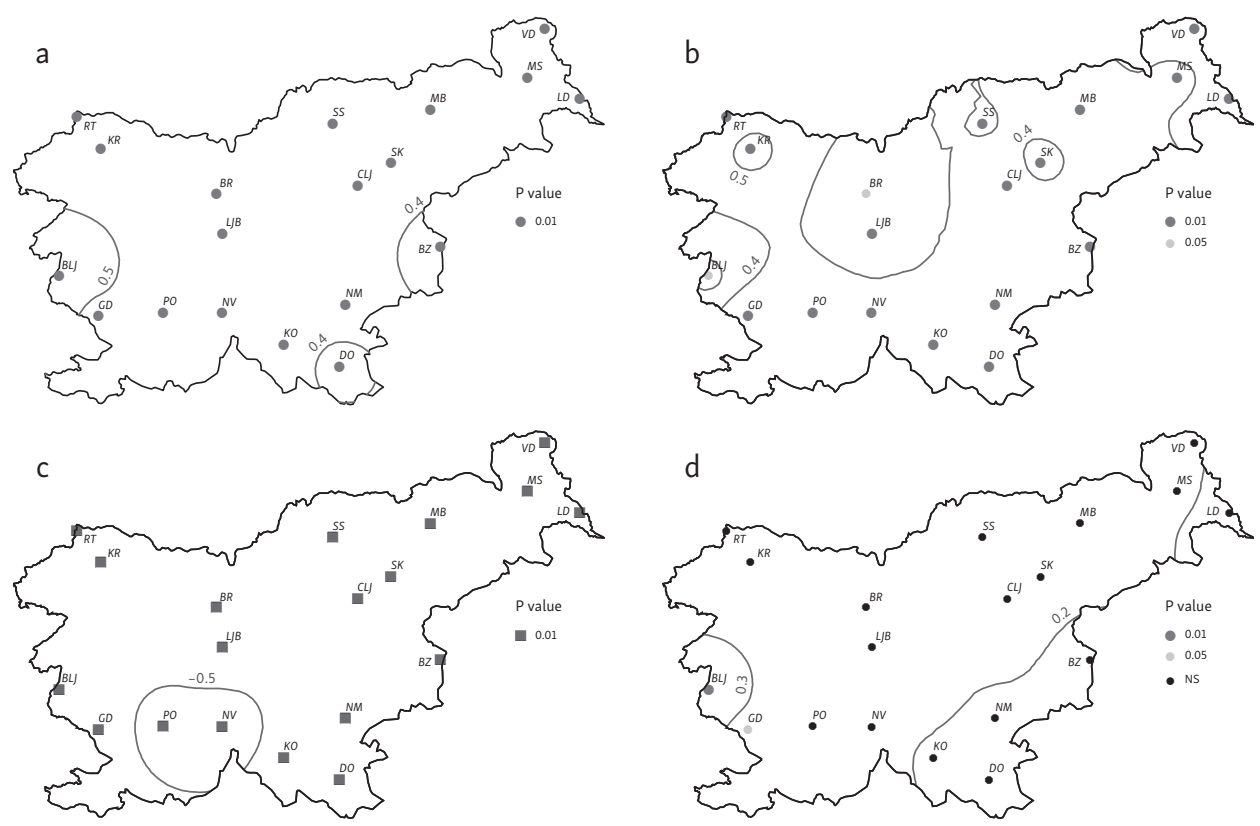

Fig. 4 - Spatial distribution of the Spearman's rank correlation coefficient between spring $T_{\max }$ and the atmospheric circulation pattern indices ( $a-A O i, b-E A i, c-S C A N D i, d-N A O i)$ in Slovenia during the 1963-2014 period. Significant at: $p<0.01$ and $p<0.05$. NS - nonsignificant. Circle - positive correlation and square - negative correlation.

country with significant negative correlations (from -0.427 to -0.539 ) more pronounced in south-western Slovenia (Fig. 4c). Contrary to winter, significant influence of the MO pattern was not noticed, while the NAO pattern influence had reduced and was noticed in a small area near the Adriatic coast (Fig. 4d). As in winter, significant influences of EA/WR, ENSO and WeMO atmospheric circulations were not registered in spring (Table 2).

In summer, EA pattern had the strongest influence on $T_{\max }$ distribution in Slovenia with statistically significant positive correlations (0.525 to 0.722) most pronounced in south-western Slovenia (Fig. 5a). The significant negative influence of SCAND pattern on $T_{\max }$ (from -0.344 to -0.507) was more evident in western Slovenia (Fig. 5b). The connection of EA/WR pattern and $T_{\max }$ was noticed in largest part of the country with significant negative correlations (from -0.283 to -0.406 ) more apparent in central Slovenia (Fig. 5c). Other patterns did not show significant influence on $T_{\max }$ distribution in majority of the study domain (Table 2).

Correlations between $T_{\max }$ and atmospheric circulation patterns had been weaker in autumn compared to other seasons. Only for the EA pattern significant 

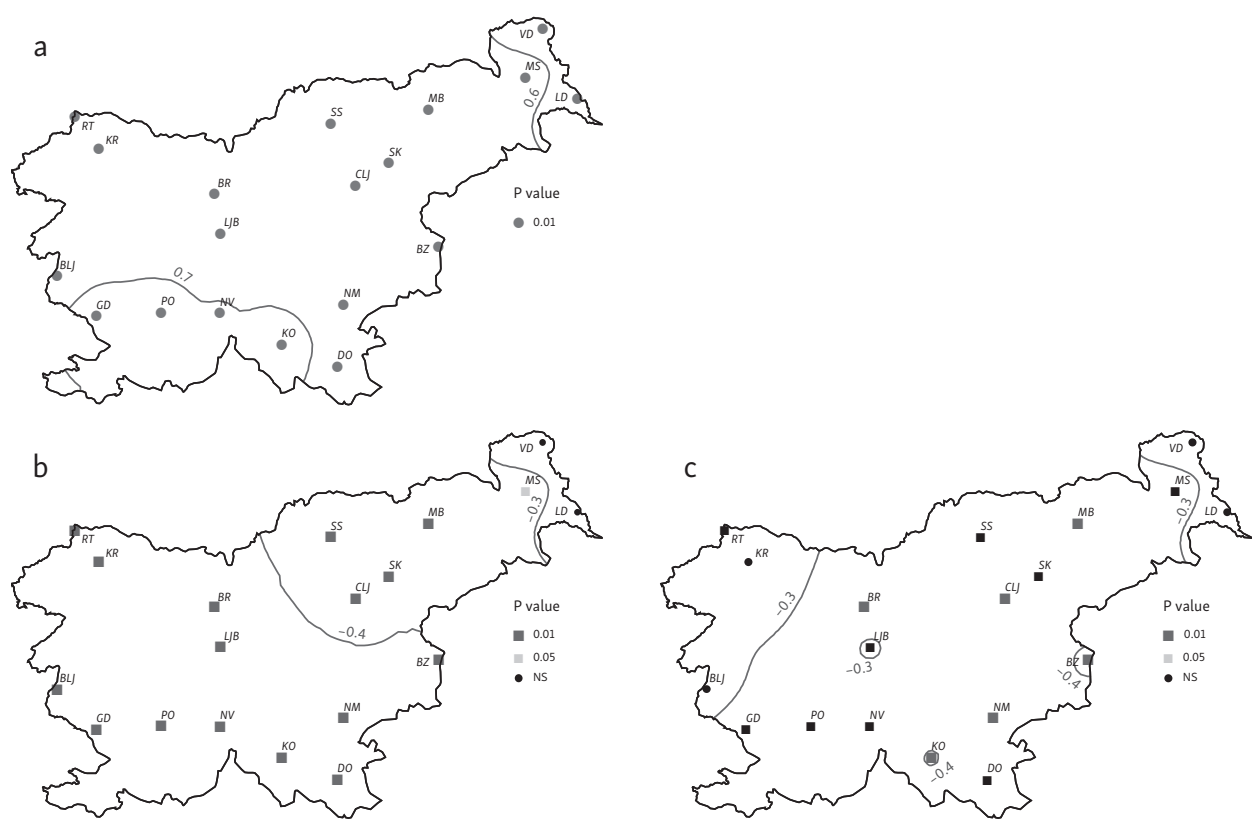

Fig. 5 - Spatial distribution of the Spearman's rank correlation coefficient between summer $T_{\max }$ and the atmospheric circulation pattern indices ( $a$ - Eai; b - SCANDi; c - EA/WRi) in Slovenia during the 1963-2014 period. Significant at: $p<0.01$ and $p<0.05$. NS - nonsignificant. Circle - positive correlation and square - negative correlation.

positive influence (from 0.352 to 0.497 ) was noticed throughout the country (Fig. 6a). The relationship between the ENSO pattern and $T_{\max }$ was stronger in central and eastern Slovenia (from 0.282 to 0.361; Fig. 6b), whereas western Slovenia was under significant positive influence of $\mathrm{AO}$ (from 0.273 to 0.328 ; Fig. 6c). Other atmospheric patterns did not show significant correlations with $T_{\max }$ in the larger part of the country (Table 2).

At annual timescale, the results suggested a predominant positive influence of the EA (with correlation coefficients from 0.500 to 0.682 ) and AO pattern (from 0.391 to 0.656 ) on $T_{\max }$ variability throughout the country with more intense association westward (Fig. 7a and 7b). Figure 7c summarizes the role of the SCAND pattern with significant negative correlations across the study domain (from -0.278 to -0.396) except for easternmost part of the country. The WeMO experienced a northeast-southwest gradient of correlation coefficients with more intense association (from -0.286 to -0.443 ) in areas near the Adriatic coast (Fig. $7 \mathrm{~d}$ ). The MO pattern significantly influenced $T_{\max }$ in north-western Slovenia (Fig. 7e) with correlations from 0.280 to 0.314 . On the other hand, the relationships between the EA/WR pattern and mean annual $T_{\max }$ were significant (from -0.276 to -0.294 ) in 
north-eastern Slovenia (Fig. 7f). ENSO and NAO patterns did not show significant correlation with $T_{\max }$ on annual level (Table 2).

\section{Discussion and conclusions}

The statistical analysis of annual and seasonal data from a network of meteorological stations in Slovenia from 1963 to 2014 has allowed for quantitatively characterizing $T_{\max }$ variability in the study area and for assessing similarities and differences with respect to $T_{\max }$ fluctuations in other areas of the Mediterranean region.

On annual and seasonal level, the highest $T_{\max }$ are registered in western, Sub-mediterranean Slovenia near the Adriatic coast with their decrease towards the north and east of the country. This is due to the fact that western Slovenia is exposed to the inflow of warm air from the Adriatic Sea and to topographicallyinduced $T_{\max }$ reduction towards the north and east Slovenia.

Positive trends of $T_{\max }$ are observed in all seasons and at annual timescale. Significant increase on all stations is noticed in summer (from $0.4^{\circ} \mathrm{C}$ to $0.7^{\circ} \mathrm{C} \cdot \operatorname{decade}^{-1}$ )
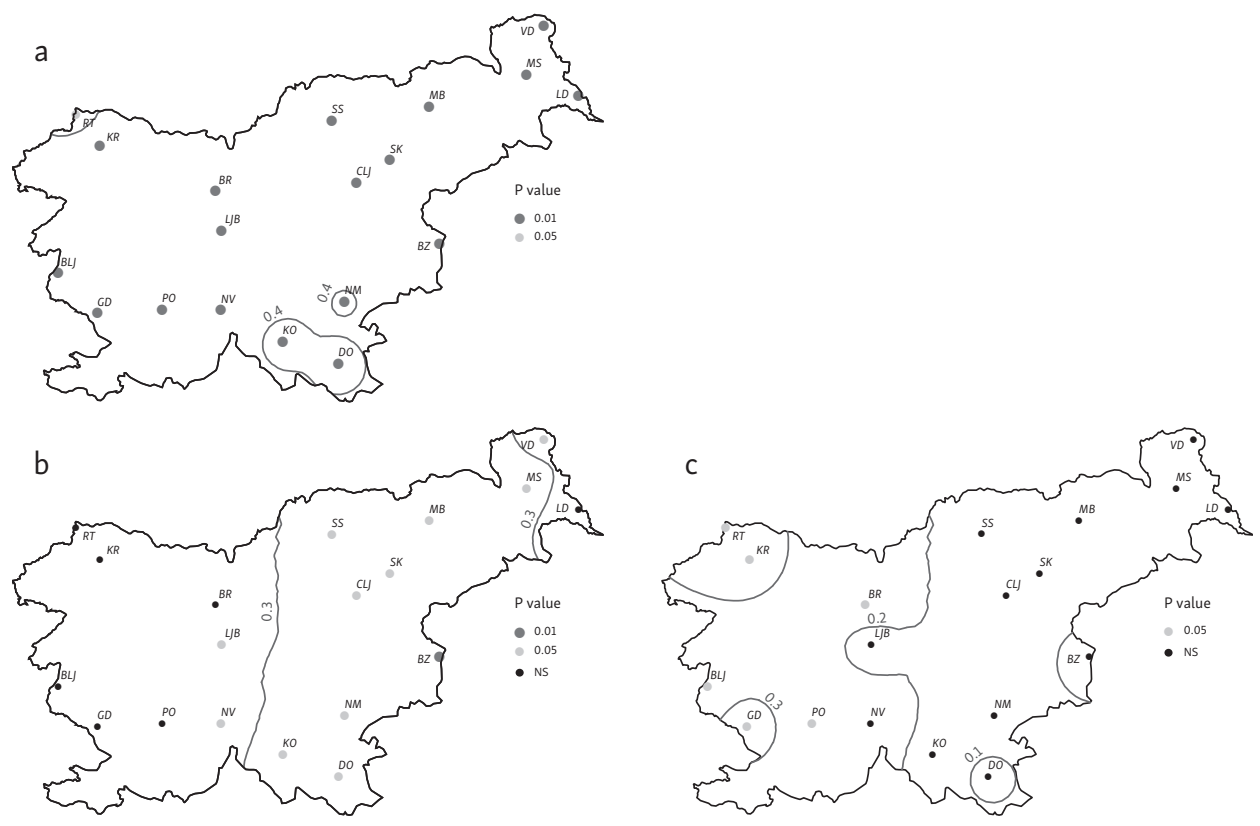

Fig. 6 - Spatial distribution of the Spearman's rank correlation coefficient between autumn $T_{\max }$ and the atmospheric circulation pattern indices ( $a$ - EAi, b - ENSOi, c - AOi) in Slovenia during the 1963-2014 period. Significant at: $p<0.01$ and $p<0.05$. NS - nonsignificant. Circle - positive correlation and square - negative correlation. 

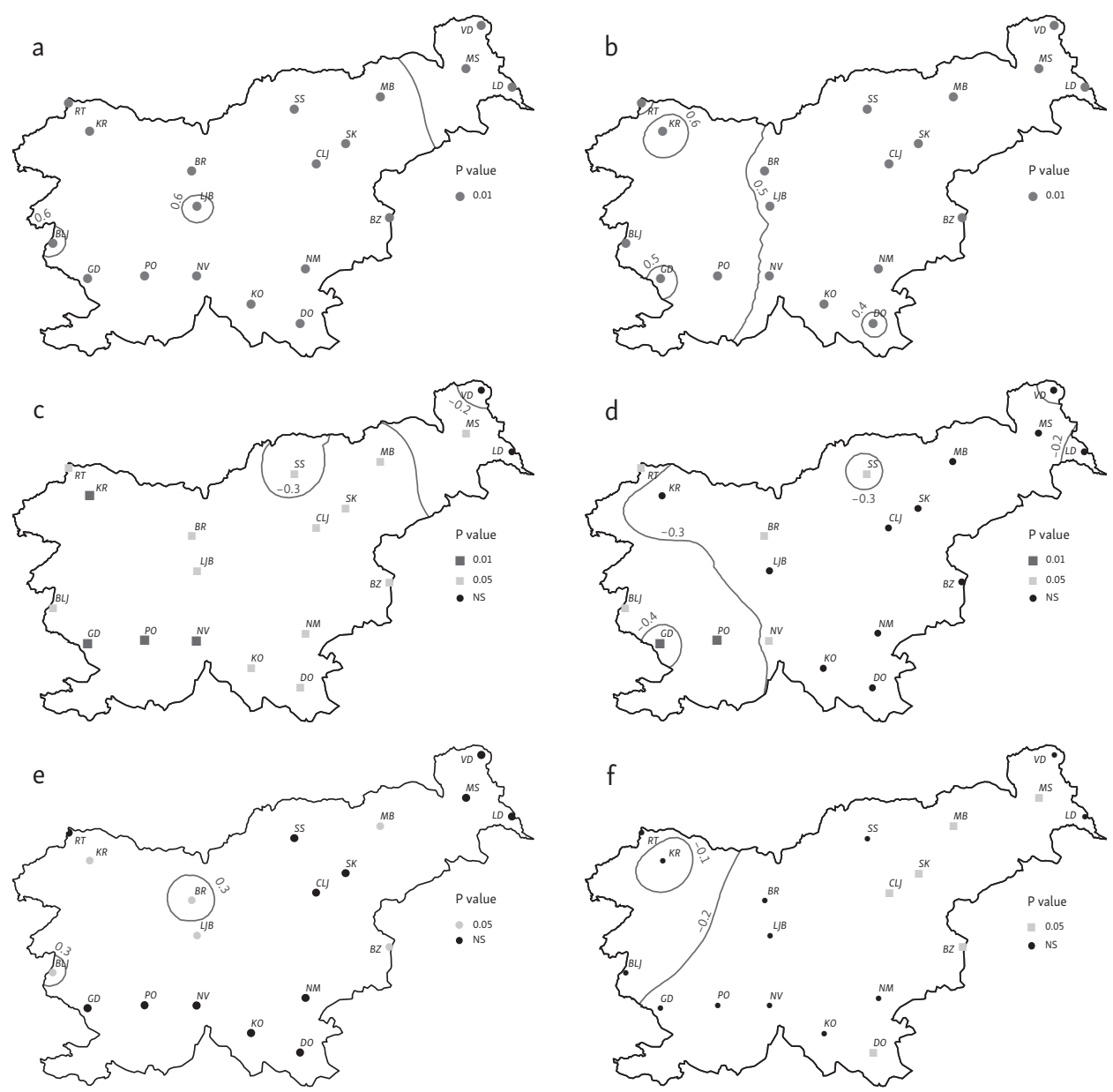

Fig. 7 - Spatial distribution of the Spearman's rank correlation coefficient between annual $T_{\max }$ and the atmospheric circulation pattern indices ( $a$ - EAi, b - Aoi, c - SCANDi, $d$ - WeMOi, e - MOi, $f-E A$ / WRi) in Slovenia during the 1963-2014 period. Significant at: $p<0.01$ and $p<0.05$. NS - nonsignificant. Circle - positive correlation and square - negative correlation.

and spring (from $0.4^{\circ} \mathrm{C}$ to $0.6^{\circ} \mathrm{C} \cdot$ decade $^{-1}$ ) and at annual timescale (from $0.3^{\circ} \mathrm{C}$ to $0.5^{\circ} \mathrm{C} \cdot$ decade $\left.^{-1}\right)$. Significant but less apparent increase is observed in winter on majority of the stations. Autumn is characterized by lowest rate of $T_{\max }$ increase. $T_{\max }$ trends have a spatial component on annual and seasonal level. More intense temperature increase is noticed in central and eastern Slovenia compared to northwestern, mountainous Slovenia at all investigated timescales. Increased zonal circulation and the dominance of the Atlantic anticyclones over Western Europe (El Kenawy et al. 2012) may be linked to the observed warming in $T_{\max }$ 
in Slovenia. Decreasing trend of snow cover (Žagar, Kajfež-Bogataj, Črepinšek 2006) and glacier retreat (Gabrovec 2002) was observed in Slovenia as a consequence of temperature rise in winter. Furthermore, earlier occurrence of spring phenological phases of plants and later ending of autumn phenological phases was significantly correlated with increases in mean, maximum and minimum air temperature in Slovenia (Milošević, Žiberna, Savić 2013). $T_{\max }$ increase in Slovenia is comparable to the previous work regarding northeastern Spain (El Kenawy, Lopez-Moreno, Vicente-Serrano 2012), the Iberian Peninsula (Martínez et al. 2010), the Mediterranean (Brunetti et al. 2006) and Europe (Jones et al. 1999). For example, El Kenawy, Lopez-Moreno, Vicente-Serrano (2012) indicated that majority of observations in northeastern Spain showed warming trend in annual, summer, winter, and spring temperature, respectively. The only exception was noticed in autumn since observatories exhibited a negative tendency in the majority of the observations. In general, an increase in annual and seasonal mean maximum and mean minimum temperature occurred at mountain meteorological stations in Croatia during the second half of the $20^{\text {th }}$ century. The increase in mean maximum was faster than in the mean minimum temperatures (Gajić-Čapka, Zaninović 1997).

Correlations between atmospheric circulation patterns and $T_{\max }$ in Slovenia were analyzed and general results are acquired. The results suggest predominant positive influence of EA and AO patterns and negative influence of SCAND pattern on interannual variability of $T_{\max }$ throughout the country. Positive phase of EA pattern causes strong zonal flow over the East Atlantic and Europe (Knežević et al. 2014) bringing warmer air and increasing $T_{\max }$ in Slovenia. Similarly, positive phase of AO leads to $T_{\max }$ increase in the country due to the reinforcement of westerly winds that bring warmth toward Europe. Contrarily, positive SCAND configuration is associated cold air masses causing lower $T_{\max }$ in the country.

On seasonal level, only significant positive influence of the EA pattern on $T_{\max }$ in Slovenia is present in all seasons. Similarly, Toreti et al. (2010) reported positive linear correlation of seasonal temperaturein Italy with the EA pattern in all seasons but autumn. Furthermore, the positive phase of EA caused more warm days in Iberian Peninsula (Rodríguez-Puebla et al. 2010) and warm nights and days as well as tropical days in Serbia (Unkašević, Tošić 2013; Knežević et al. 2014). The $\mathrm{AO}$ pattern has the most widespread geographical influence on spring and winter $T_{\max }$ in Slovenia. Its positive phase corresponds to the warm weather conditions and air temperature rise in the country. Similarly, AO influence on air temperature was also noticed in Northern Italy during all seasons, except summer (Toreti et al. 2010). Relationships between $T_{\max }$ and SCAND pattern are negative and pronounced in the warmer part of the year (spring and summer), while significant negative influence of the EA/WR pattern is present only in summer in Slovenia. In Northern Italy, SCANDi showed significant negative correlation only with summer 
temperature (Toreti et al. 2010). Rodríguez-Puebla et al. (2010) reported that the increase in $T_{\max }$ in Iberian Peninsula were linked to an increase in geopotential height at $500 \mathrm{hPa}$ and a decrease in the SCANDi. Significant positive correlations are found between positive phase of $\mathrm{NAO}$ as well as $\mathrm{MO}$ and $\mathrm{T}_{\max }$ only during winter in Slovenia leading to air temperature increase. Furthermore, the NAO correlated positively and significantly with $T_{\max }$ during winter in NE Spain (El Kenawy, LopezMoreno, Vicente-Serrano 2012). Efthymiadis et al. (2011) reported that the MOi seems to have the most widespread geographic influence for winter temperature extremes in the Mediterranean basin. Significant positive correlations between $T_{\max }$ and ENSO pattern are noticed only during autumn in Slovenia causing air temperature increase. Similarly, Donat et al. (2014) reported strong positive effect of ENSO pattern on $T_{\max }$ in the eastern part of the Arab region (from north-west Africa to the Arabian Peninsula). Of all patterns, only WeMO did not show significant influence on seasonal $T_{\max }$ variability in Slovenia. Contrarily, El Kenawy, Lopez-Moreno, Vicente-Serrano (2012) reported significant negative influence of the WeMO pattern on air temperatures in NE Spain during warm seasons.

Results from the study contribute to the better understanding of relationships between atmospheric circulation patterns and $T_{\max }$ variability in Slovenia. However, atmospheric circulation variability alone is not able to explain the observed year-to-year $T_{\max }$ variations and their trends. The influence of other factors such as blocking conditions, mesoscale patterns, sea surface temperatures, soil moisture, cloudiness, etc. should be investigated in future in order to acquire a more detailed picture about climatic change in this country and its causes.

\section{References}

AGUILAR, E., AUER, I., BRUNET, M., PETERSON, T.C., WIERINGA, J. (2003): Guidelines on climate data and homogenization. Report WMO-TD 1186, WCDMP No. 53, Geneva.

ALEXANDERSSON, H. (1986): A homogeneity test applied to precipitation data. Journal of Climate, 6, 661-675.

BRANKOVIĆ, Č., PATARČIĆ, M., GÜTLLER, I., SRNEC, L. (2012): Near-future climate change over Europe with focus on Croatia in an ensemble of regional climate model simulations. Climate Research, 52, 227-251.

BRUNETTI, M., MAUGERI, M., MONTI, F., NANNI, T. (2006): Temperature and precipitation variability in Italy in the last two centuries from homogenised instrumental time series. International Journal of Climatology, 26, 345-381.

DE LUIS, M., ČUFAR, K., SAZ, M.A., LONGARES, L.A., CEGLAR, A., KAJFEŽ-BOGATAJ, L. (2014): Trends in seasonal precipitation and temperature in Slovenia during 1951-2007. Regional Environmental Change, 14, 1801-1810.

DOBROVOLNÝ, P., BRÁZDIL, R., KOTYZA, O., VALÁŠEK, H. (2010): Extreme summer and winter temperatures in the Czech Lands after A.D. 1500 and their Central European context. Geografie, 115, 3, 266-283. 
DONAT, M.G., PETERSON, T.C., BRUNET, M., KING, A.D., ALMAZROUI, M., KOLLI, R.K., BOUCHER, DJ., AL-MULLA, A.Y., NOUR, A.Y., ALY, A.A., NADA, T.A.A., SEMAWI, M.M., AL DASHTI, A.D., SALHAB, T.G., EL FADLI, K.I., MUFTAH, M.K., EIDA, S.D., BADI, W., DRIOUECH, F., EL RHAZ, K., ABUBAKER, M.J.Y., GHULAM, A.S., ERAYAH, A.S., MANSOUR, M.B., ALABDOULI, W.O., AL DHANHANI, J.S., AL SHEKAILI, M.N. (2014): Changes in extreme temperature and precipitation in the Arab region: long-term trends and variability related to ENSO and NAO. International Journal of Climatology, 34, 581-592.

DUBROVSKÝ, M., HAYES, M., DUCE, P., TRNKA, M., SVOBODA, M., ZARA, P. (2014): MultiGCM projections of future drought and climate variability indicators for the Mediterranean region. Regional Environmental Change, 14, 1907-1919.

EFTHYMIADIS, D., GOODESS, C.M., JONES, P.D. (2011): Trends in Mediterranean gridded temperature extremes and large-scale circulation influences. Natural Hazards and Earth System Sciences, 11, 2199-2214.

EL KENAWY, A., LOPEZ-MORENO, J.I., VICENTE-SERRANO, S.M. (2012): Trend and variability of surface air temperature in northeastern Spain (1920-2006): Linkage to atmospheric circulation. Atmospheric Research, 106, 159-180.

GABROVEC, M. (2002): Changes in the volume of the Triglav Glacier. Dela, 18, 133-141.

GAJIĆ-ČAPKA, M., ZANINOVIĆ, K. (1997): Changes in Temperature Extremes and Their Possible Causes at the SE Boundary of the Alps. Theoretical and Applied Climatology, 57, 1-2, 89-94.

GIORGI, F. (2006): Climate change hot-spots. Geophysical Research Letters, 33, 1-4.

GULLETT, D.W., VINCENT, L., SAJECKI, P.J.F. (1990): Testing for homogeneity in temperature time series at Canadian climate stations. Atmospheric Environment Service, Downsview, Ontario, CCC Report No. 90-4, 1-43.

HEINO, R. (1994): Climate in Finland during the Period of Meteorological Observation. Academic dissertation. Finnish Meteorological Institute Contributions 12, Helsinki, 1-209.

HURRELL, J.W. (1995): Decadal trend in the North Atlantic oscillation: regional temperature and precipitation. Science, 269, 676-679.

HURRELL, J.W., VAN LOON, H. (1997): Decadal variations in climate associated with the North Atlantic oscillation. Climatic Change, 36, 301-326.

JACOBEIT, J., HERTIG, E., SEUBERT, S., LUTZ, K. (2014): Statistical downscaling for climate change projections in the Mediterranean region: methods and results. Regional Environmental Change, 14, 5, 1891-1906.

JONES, P.D., RAPER, S.C.B., SANTER, B., CHERRY, B.S.B., GOODESS, C., KELLY, P.M., WIGLEY, T.M.L., BRADLEY, R.S., DIAZ, H.F. (1985): A grid point surface air temperature data set for the Northern Hemisphere. TRO22, Department of Energy, Washington, 1-250.

JONES, P.D., NEW, M., PARKER, D.E., MARTIN, S., RIGOR, I.G. (1999): Surface air temperature and its changes over the past 150 years. Reviews of Geophysics, 37, 173-199.

KARL, T.R., WILLIAMS, C.N. jr. (1987): An approach to adjusting climatological time series for discontinuous inhomogeneities. Journal of Climate and Applied Meteorology, 26, 1744-1763.

KENYON, J., HEGERL, G.C. (2008): Influence of modes of climate variability on global temperature extremes. Journal of Climate, 21, 15, 3872-3889.

KHALIQ, M.N., OUARDA, T. (2007): On the critical values of the standard normal homogeneity test (SNHT). International Journal of Climatology, 27, 681-687.

KNEŽEVIĆ, S., TOŠIĆ, I., UNKAŠEVIĆ, M., PEJANOVIĆ, G. (2014): The influence of the East Atlantic Oscillation to climate indices based on the daily minimum temperatures in Serbia. Theoretical and Applied Climatology, 116, 435-446. 
KOTTEK, M., GRIESER, J., BECK, C., RUDOLF, B., RUBEL, F. (2006): World map of the Köppen-Geiger climate classification updated. Meteorologische Zeitschrift, 15, 259-263.

LIONELlO, P., ABRANTES, F., GACIC, M., PLANTON, S., TRIGO, R., ULBRICH, U. (2014): The climate of the Mediterranean region: research progress and climate change impacts. Regional Environmental Change, 14, 1679-1684.

MARTÍNEZ, M.D., SERRA, C., BURGUEÑO, A., LANA, X. (2010): Time trends of daily maximum and minimum temperatures in Catalonia (NE Spain) for the period 1975-2004. International Journal of Climatology, 30, 267-290.

MILOŠEVIĆ, D., SAVIĆ, S., ŽIBERNA, I. (2013): Analysis of the climate change in Slovenia: fluctuations of meteorological parameters for the period 1961-2011 (Part I). Bulletin of the Serbian Geographical Society, 93, 1, 1-14.

MILOŠEVIĆ, D., ŽIBERNA, I., SAVIĆ, S. (2013): Analysis of the climate change in Slovenia: changes in plant development under the influence of meteorological parameters in the period 1961-2011 (Part II). Bulletin of the Serbian Geographical Society, 93, 2, 1-22.

MOBERG, A., ALEXANDERSSON, H. (1997): Homogenization of Swedish temperature data. Part II: homogenized gridded air temperature compared with a subset of global gridded air temperature since 1861. International Journal of Climatology, 17, 35-54.

MOBERG, A., JONES, P. J., LISTER, D., WALTHER, A., BRUNET, M., JACOBEIT, J., ALEXANDER, L.V., DELLA-MARTA, P.M., LUTERBACHER, J., YIOU, P., CHEN, D., KLEIN TANK, A.M.G., SALADIE, O., SIGRO, J., AGUILAR, E., ALEXANDERSSON, H., ALMARZA, C., AUER, I., BARRIENDOS, M., BEGERT, M., BERGSTROM, H., BOHM, R., BUTLER, C.J., CAESAR, J., DREBS, A., FOUNDA, D., GERSTENGARBE, F.W., MICELA, G., MAUGERI, M., OSTERLE, H., PANDZIC, K., PETRAKIS, M., SRNEC, L., TOLASZ, R., TUOMENVIRTA, H., WERNER, P.C., LINDERHOLM, H., PHILIPP, A., WANNER, H., XOPLAKI, E. (2006): Indices for daily temperature and precipitation extremes in Europe analyzed for the period 1901-2000. Journal of Geophysical Research, 111, 1-25.

OGRIN, D. (2004): Modern climate change in Slovenia. In: Orožen Adamič, M. (ed.): Slovenia: a geographical overview. ZRC SAZU, Ljubljana, 45-50.

OGRIN, D., PRUT, D. (2009): Aplikativna fizična geografija Slovenije. Znantstvena založba Fikozofske fakultete, Ljubljana.

OROŽEN ADAMIČ, M. (2004): About Slovenia. In: Orožen Adamič, M. (ed.): Slovenia: a geographical overview. ZRC SAZU, Ljubljana, 7-9.

PERKO, D. (1998): The regionalization of Slovenia. Geografski zbornik, 38, 12-57.

PETERSON, T.C., EASTERLING, D.R., KARL, T.R., GROISMAN, P., NICHOLLS, N., PLUMMER, N., TOROK, S., AUER, I., BOEHM, R., GULLETT, D., VINCENT, L., HEINO, R., TUOMENVIRTA, H., MESTRE, O., SZENTIMREY, T., SALINGER, J., FØRLAND, E.J., HANSSEN-BAUER, I., ALEXANDERSSON, H., JONES, P., PARKER, D. (1998): Homogeneity adjustments of In Situ atmospheric climate data: A review. International Journal of Climatology, 18, 1493-1517.

RODRÍGUEZ-PUEBLA, C., ENCINAS, A.H., GARCÍA-CASADO, L.A., NEITO, S. (2010): Trends in warm days and cold nights over the Iberian Peninsula: relationships to large-scale variables. Climatic Change, 100, 667-684.

SALMI, T., MÄTTÄ, A., ANTTILA, P., RUOHO-AIROLA, T., AMNELL, T. (2002): Detecting trends of annual values of atmospheric pollutants by the Mann-Kendall test and Sen's slope estimates. The Excel template application MAKESENS. Helsinki, Finnish Meteorological Institute, 1-35. 
SAVIĆ, S., PETROVIĆ, P., MILOVANOVIĆ, B. (2010): Homogenisation of mean air temperature data series from Serbia. European Geosciences Union-General Assembly 2010, Vienna, Austria, 02-07 May 2010, Geophysical Research Abstract Vol. 12, EGU2010-5521-1.

SAVIĆ, S., MILOŠEVIĆ, D., MARKOVIĆ, V., KUJUNDŽIĆ-DAČOVIĆ, R. (2012): Homogenisation of Mean Air Temperature Time Series from Vojvodina (North Serbia). Geographica Pannonica, 16, 2, 38-43.

SAVIĆ, S., MILOVANOVIĆ, B., LUŽANIN, Z., LAZIĆ, L., DOLINAJ, D. (2014): The variability of extreme temperatures and their relationship with atmospheric circulation: the contribution of applying linear and quadratic models. Theoretical and Applied Climatology, DOI 10.1007/ s00704-014-1263-3.

SIMOLO, C., BRUNETTI, M., MAUGERI, M., NANNI, T. (2014): Increasingly warm summers in the Euro-Mediterranean zone: mean temperatures and extremes. Regional Environmental Change, 14, 5, 1825-1832.

SUŠELJ, K., BERGANT, K. (2006): Sredozemski oscilacijski indeks in vpliv na podnebje Slovenije. In: Kozmus, K., Kuhar, M. (ed.): Raziskave s področja geodezije in geofizike: zbornik predavanj. Faculty of Civil and Geodetic Engineering, Ljubljana, 1-10.

SNEYERS, R. (1990): On the statistical analysis of series of observations. Genève, World Meteorological Organization, Technical Note, 415.

ŠTĚPÁNEK, P. (2007): AnClim - software for time series analysis. Department of Geography, Faculty of Natural Sciences, MU, Brno, 1.47 MB http://www.climahom.eu/AnClim.html.

TORETI, A., DESIATO, F., FIORAVANTI, G., PERCONTI, W. (2010): Seasonal temperatures over Italy and their relationship with low-frequency atmospheric circulation patterns. Climatic Change, 99, 211-227.

TUOMENVIRTA, H. (2001): Homogeneity adjustments of temperature and precipitation series - Finnish and Nordic data. International Journal of Climatology, 21, 495-506.

UNKAŠEVIĆ, M., TOŠIĆ, I. (2013): Trends in temperature indices over Serbia: relationships to large-scale circulation patterns. International Journal of Climatology, 33, 3152-3161.

VAUTARD, R., GOBIET, A., JACOB, D., BELDA, M., COLETTE, A., DÉQUÉ, M., FERNÁNDEZ, J., GARCÍA-DÍEZ, M., GOERGEN, K., GÜTTLER, I., HALENKA, T., KARACOSTAS, T., KATRAGKOU, E., KEULER, K., KOTLARSKI, S., MAYER, S., VAN MEIJGAARD, E., NIKULIN, G., PATARČIĆ, M., SCINOCCA, J., SOBOLOWSKI, S., SUKLITSCH, M., TEICHMANN, C., WARRACH-SAGI, K., WULFMEYER, V., YIOU, P. (2013): The simulation of European heat waves from an ensemble of regional climate models within the EUROCORDEX project. Climate Dynamics, 41, 9, 2555-2575.

VERTAČNIK, G., DOLINAR, M., BERTALANIČ, R., KLANČAR, M., DVORŠEK, D., NADBATH, M. (2015): Ensemble homogenisation of Slovenian monthly air temperature series. International Journal of Climatology, DOI: 10.1002/joc.4265.

ŽAGAR, T., KAJFEŽ-BOGATAJ, L., ČREPINŠEK, Z. (2006): Časovna analiza nekaterih klimatskih spremenljivk v Sloveniji. Acta agriculturae Slovenica, 87, 2, 285-298. 


\section{SHRNUTÍ}

\section{Maximální teploty ve Slovinsku a jejich vztah k průběhu atmosférické cirkulace}

Článek zkoumá vývoj průběhu ročních a sezónních maximálních teplot $\left(T_{\max }\right)$ ve Slovinsku a jejich vztah s průběhem atmosférické cirkulace. Průměrná roční $T_{\max }$ kolísá od $1,5^{\circ} \mathrm{C} v$ severozápadní, alpské části Slovinska až po $18,2^{\circ} \mathrm{C}$ v jihozápadní, středozemní části Slovinska. Podobné prostorové rozdělení je patrné u průměrné sezónní $T_{\max }$, kde se hodnoty pohybují od $-4,6^{\circ} \mathrm{C}$ po $8,6^{\circ} \mathrm{C}$ v zimě, od $-0,7^{\circ} \mathrm{C}$ po $17,8^{\circ} \mathrm{C}$ na jaře, od $8,4^{\circ} \mathrm{C}$ po $27,7^{\circ} \mathrm{C}$ v létě a od $3,0^{\circ} \mathrm{C}$ po $18,7^{\circ} \mathrm{C}$ na podzim. Jaro je teplejší než podzim ve většině stanic v zemi s výjimkou jihozápadního středozemního Slovinska. Nejnižší sezónní výkyvy $T_{\max }$ jsou zaznamenávány v oblasti poblíž Jaderského moře, kam zasahují submediteránní klimatické vlivy.

Během období 1963-2014 se průměrné roční $T_{\max }$ ve Slovinsku podstatně zvyšovaly od $0,3^{\circ} \mathrm{C}$ až po $0,5^{\circ} \mathrm{C}$ za desetiletí. Tento př́růstek byl pozorován v celé zemi, ovšem v severozápadním Slovinsku byla jeho míra nižší. Na úrovni ročních období bylo oteplování intenzivnější v létě (od $0,4^{\circ} \mathrm{C}$ po $0,7^{\circ} \mathrm{C}$ za desetiletí) a na jaře (od $0,4^{\circ} \mathrm{C}$ po $0,6^{\circ} \mathrm{C}$ za desetiletí), přičemž vyšší míra byla dosažena ve středním a východním Slovinsku. Oteplování je méně intenzivní v zimě (od $0,2^{\circ} \mathrm{C}$ po $0,6^{\circ} \mathrm{C}$ za desetiletí) a na podzim (od $0,1^{\circ} \mathrm{C}$ po $0,3^{\circ} \mathrm{C}$ za desetiletí), přičemž v severozápadním a jihovýchodním Slovinsku byly sledovány méně podstatné trendy.

Během zimy jsou patrné statisticky významné pozitivní korelace mezi $T_{\max }$ a indexem Arktické oscilace (AOi; od 0,366 po 0,562), indexem Severoatlantické oscilace (NAOi; od 0,387 po 0,540), indexem Středomořské oscilace (Moi; od 0,318 po 0,538) a indexem Východoatlantické oscilace (EAi; od 0,328 po 0,452 ) po celém Slovinsku. Nejsilnější vliv průběhu atlantických oscilací je zjevný v severozápadním Slovinsku, zatímco vliv průběhu Severoatlantické oscilace a Východoatlantické oscilace je nejsilnější ve středním Slovinsku a Středomořské oscilace v severním Slovinsku. Závažné negativní korelace jsou zaznamenávány mezi $T_{\max }$ a indexem Skandinávské oscilace (SCANDi; od -0,278 po -0,399) v západní části země. Průběh jiné atmosférické cirkulace, jako například Východoatlantické/Západoruské oscilace (EA/WR), Jižní oscilace El Niňo (ENSO) a Západní středomořské oscilace (WeMO), nevykázal signifikantní korelaci s T max. Významné pozitivní korelace mezi $T_{\max }$ a AOi (od 0,369 po 0,605) a EAi (od 0,278 po 0,537) jsou zjevné na jaře po celé zemi. Vliv průběhu $A O$ je výraznější v západním Slovinsku a průběhu EA v severozápadním a jižním Slovinsku. Vliv průběhu SCAND sílí na jaře a lze ho pozorovat v celé zemi, přičemž podstatné negativní korelace (od -0,427 po -0,539) jsou výraznější v jihozápadním Slovinsku. Na rozdíl od zimy není patrný podstatný vliv MO, přičemž vliv průběhu NAO je omezený a projevuje se v malé oblasti u jaderského pobřeží. Tak jako v zimě výraznější vliv atmosférické cirkulace EA/WR, ENSO a WeMO nebyl zpozorován ani na jaře. V létě má průběh EA nejsilnější vliv na rozložení $T_{\max }$ ve Slovinsku se statisticky významnými pozitivními korelacemi $(0,525$ po 0,722), nejvýrazněji v jihozápadním Slovinsku. Podstatný negativní vliv průběhu SCAND na $T_{\max }$ (od -0,344 po -0,507) je zjevnější v západním Slovinsku. Souvislost průběhu EA/WR a $T_{\max }$ je pozorována v největší části země s podstatně negativními korelacemi (od -0,283 po-0,406), evidentními ve středním Slovinsku. Další průběhy nevykazují podstatný vliv rozložení na $T_{\max }$ ve většině studované oblasti. Ve srovnání s jinými obdobími jsou korelace mezi $T_{\max }$ a průběhem atmosférické cirkulace slabší na podzim. Jenom podstatný pozitivní vliv průběhu EA (od 0,352 po 0,497) je sledovatelný po celé zemi. Vztah mezi průběhem ENSO a T $T_{\max }$ je těsnější ve středním a východním Slovinsku (od 0,282 po 0,361), přičemž západní Slovinsko je pod podstatným pozitivním vlivem AO (od 0,273 po 0,328). Další atmosférické průběhy nevykazují podstatnější korelaci s $T_{\max }$ ve větší části země. U ročního časového měřítka z výsledků vyplývá 
převážně pozitivní vliv průběhu EA (od 0,500 po 0,682) a AO (od 0,391 po 0,656) na variabilitu $\mathrm{T}_{\max }$ po celé zemi se sílící intenzitou západním směrem. Průběh SCAND měl podstatné negativní korelace s $T_{\max } \mathrm{v}$ celé sledované oblasti (od -0,278 po -0,396) až na nejvýchodnější část země. WeMO zaznamenává severovýchodně-jihozápadní gradient s intenzivnější vazbou (od -0,286 po -0,443) v oblastech poblíž jaderského pobřeží. Průběh MO podstatně ovlivňuje $T_{\max } \mathrm{v}$ severozápadním Slovinsku s korelacemi od 0,280 po 0,314. Na druhou stranu vztah mezi průběhem EA/WR a průměrnou roční $T_{\max }$ je podstatný (od -0,276 po -0,294) v severovýchodním Slovinsku. Průběh ENSO a NAO nevykázal signifikantní korelaci s maximální teplotou na roční úrovni.

Výsledky této studie přispěly k lepšímu chápání vztahů mezi atmosférickou cirkulací a proměnlivostí $T_{\max }$ ve Slovinsku. Avšak proměnlivost atmosférické cirkulace sama o sobě neumí vysvětlit pozorované výkyvy $T_{\max } \mathrm{z}$ roku na rok a jejich trendy. Vliv dalších faktorů, jako je třeba přerušení proudění, povětrnostní poměry na střední úrovni, teplota mořské hladiny, půdní vlhkost, oblačnost atd. by měl být zkoumán v budoucích příspěvcích, aby se získal podrobnější obrázek klimatických změn v této zemi a jejich příčiny.

Obr. 1 Prostorové rozdělení průměrné $T_{\max }$ ve Slovinsku v období 1963-2014; a - roční úroveň; b - zima; c - jaro; d - léto; e - podzim.

Obr. 2 Prostorové rozdělení dlouhodobých trendů $T_{\max }\left({ }^{\circ} \mathrm{C}\right.$ za desetiletí) ve Slovinsku v období 1963-2014: a - roční; b - zima; c - jaro; d - léto; e - podzim. Statistická významnost na: $\mathrm{p}<0,1, \mathrm{p}<0,05, \mathrm{p}<0,01$ a $\mathrm{p}<0,001$. NS - nepodstatný.

Obr. 3 Prostorové rozdělení Spearmanova koeficientu korelace mezi zimní $T_{\max }$ a indexy průběhu atmosférické cirkulace (a - AOi, b - NAOi; c - MOi; d - EAi; e - SCANDi) ve Slovinsku v období 1963-2014. Významné na: $p<0,01$ a p < 0,05. NS - nepodstatný. Kruh - pozitivní korelace a čtverec - negativní korelace.

Obr. 4 Prostorové rozdělení Spearmanova koeficientu korelace mezi jarní $T_{\max }$ a indexy průběhu atmosférické cirkulace ( $\mathrm{a}$ - AOi, b - EAi; c - SCANDi; d - NAOi) ve Slovinsku v období 1963-2014. Významné na: $\mathrm{p}<0,01$ a p < 0,05. NS - nepodstatný. Kruh - pozitivní korelace, čtverec - negativní korelace.

Obr. 5 Prostorové rozdělení Spearmanova koeficientu korelace mezi letní $T_{\max }$ a indexy průběhu atmosférické cirkulace ( $\mathrm{a}$ - EAi; b - SCANDi; c - EA/WRi) ve Slovinsku během období 1963-2014. Významné na: $\mathrm{p}<0,01$ a p < 0,05. NS - nepodstatný. Kruh - pozitivní korelace, čtverec - negativní korelace.

Obr. 6 Prostorové rozdělení Spearmanova koeficientu korelace mezi podzimní $T_{\max }$ a indexy průběhu atmosférické cirkulace ( $\mathrm{a}$ - EAi; b - ENSOi; c - AOi) ve Slovinsku během období 1963-2014. Významné na: $\mathrm{p}<0.01$ a p < 0.05. NS - nepodstatný. Kruh - pozitivní korelace, čtverec - negativní korelace.

Obr. 7 Prostorové rozdělení Spearmanova koeficientu korelace mezi roční $T_{\max }$ a indexy průběhu atmosférické cirkulace ( $\mathrm{a}$ - EAi; b - AOi; c - SCANDi; d - WeMOi ; e - MOi; f - EA/WRi) ve Slovinsku v období 1963-2014. Významné na: $\mathrm{p}<0.01$ a $\mathrm{p}<0.05$. NS nepodstatný. Kruh - pozitivní korelace, čtverec - negativní korelace.

\section{ACKNOWLEDGMENTS}

This research was partly supported by the Project No. 43002 financed by the Ministry of Education, Science and Technological Development of the Republic of Serbia. 